CORRIGENDUM

doi:10.1038/nature04909

\section{A brain-specific microRNA regulates dendritic spine development}

Gerhard M. Schratt, Fabian Tuebing, Elizabeth A. Nigh,

Christina G. Kane, Mary E. Sabatini, Michael Kiebler

\& Michael E. Greenberg

Nature 439, 283-289 (2006)

The protocol for penetratin-coupling of siRNA-like molecules used in this Article incorporated suggestions by Carol M. Troy that were based on the method described in ref. 1.

1. Davidson, T. J. et al. Highly efficient small interfering RNA delivery to primary mammalian neurons induces microRNA-like effects before mRNA degradation. J. Neurosci. 24, 10040-10046 (2004)

\section{CORRIGENDUM}

doi:10.1038/nature04910

\section{Brain-state- and cell-type-specific firing of hippocampal interneurons in vivo}

Thomas Klausberger, Peter J. Magill, László F. Márton, J. David B. Roberts, Philip M. Cobden, György Buzsáki

$\&$ Peter Somogyi

Nature 421, 844-848 (2003)

In the Methods section of this paper, the fifty-two male SpragueDawley rats were incorrectly described as having been anaesthetized with $1.25 \mathrm{mg} \mathrm{kg}^{-1}$ urethane. The actual dose of urethane was $1.25 \mathrm{~g} \mathrm{~kg}^{-1}$.

\section{CORRIGENDUM}

\section{doi:10.1038/nature04911}

\section{Universal scaling of respiratory metabolism, size and nitrogen in plants}

Peter B. Reich, Mark G. Tjoelker, Jose-Luis Machado

$\&$ Jacek Oleksyn

\section{Nature 439, 457-461 (2006)}

It has been drawn to our attention that the wording used in the first sentence after equation (1) is ambiguous. For the example used to illustrate $\frac{3}{4}$ power scaling, we implied that if metabolic rate had a body mass scaling exponent of 0.75 , a 10 -fold increase in size would increase metabolic rate 7.5-fold; however, we were referring to the power-law relationship on a log scale, which should have been clear from the context. A 10-fold increase in mass would therefore increase metabolic rate as a function of $10^{0.75}$, which is equal to a 5.62 -fold increase in metabolic rate. The apparent error in this example has no bearing on the power-law relationship or its interpretation in the paper. 